Sergej Beuk

Dom omladine Beograda

sergej.beuk@domomladine.org

https://doi.org/10.18485/rit.2021.19.35.6
UDK: $27-47$

27-534.3:37.015.31

Originalni naučni rad

Datum prijema: 10.2.2021.

\title{
PRILOZI TEORIJI HRIŠĆANSKE PEDAGOGIJE: MOLITVA KAO AGENS SOCIJALNO - PSIHOLOŠKOG RAZVOJA DECE I MLADIH
}

\begin{abstract}
Rezime
U ovom radu, autor je želeo da podvuče i naglasi teorijske odnose $i$ veze između sekularne i hrišćanske pedagogije, koja je u našoj sredini nedovoljno istražena oblast. Savremena hrišćanska pedagogija svoj akademski put započinje svetopisamskom naukom, ali i nastavlja putevima koje su utabale nauke i naučne discipline kao što su psihologija ličnosti, razvojna psihologija, pedagoška psihologija, opšta pedagogija, didaktika i mnoge druge. Za hrišćanske pedagoge, Hristos je antropološki cilj ali zanemarivanje naučno - istraživačkih rezultata neminovno vodi do dogmatizovanja i doktrinarnog zastranjivanja, kako hrišćanskih vaspitača, tako i hrišćanske pedagogije u celini. Autor naglašava da je upravo molitva ona disciplina uma koja ima dvostruko vaspitno dejstvo: slobodu izražavanja kroz specifičnu vrstu komunikacije i molitveno usmeravanje, od strane roditelja $i$ vaspitača, ka ovladavanju novim sposobnostima i navikama deteta. Crkva danas ima zadatak da vaspitava mlade u aktuelnoj sadašnjici, razumevajući njihove potrebe $i$ stremljenja, što često nije nimalo lak posao.
\end{abstract}

Ključne reči: Dete, molitva, Hristos, Crkva, razvojnost, hrišćanska pedagogija

\section{Uvod}

Hrišćansko vaspitanje i obrazovanje, kroz svoju metodološko - metodsku sveukupnost, ima za cilj proučavanje, formiranje i kreiranje pedagoških postupaka kojim dete neće isključivo sticati znaja, veštine i navike, već će biti osposobljeno da u etičkom, estetičkom i teološkom smislu živi na temeljima biblijskog vaspitnog nauka. Sekularna ali i hrišćanska pedagogija razumeju vaspitanje kao 'specifičan međuljudski odnos, zasnovan na komunikaciji kojom se želi ostvariti određeni uticaj jednih ličnosti na druge" ", ali samo hrišćanska pedagogija daje uvid u mogućnosti temeljne spoznaje bogolikosti, kroz Isusa Hristosa, poštujući sve specifičnosti uzrasta kome se obraća, a koje definiše razvojna psihologija. Njen neposredni cilj je da planski utiče na formiranje ljudskog bića kao "no-

1 Potkonjak, 1996:24. 
ve tvari" (2 Kor. 5,17, Gal. 6,15, Ef. 2,10), koja jeste "nov život" (Rim. 6,4) a po Božijoj milosti (Tit. 3, 5, 1 Pet. 1, 3). Dalje, sekularna i hrišćanska pedagogija postoje zarad svestranog razvoja ljudskih potencija (kognitivnih, konativnih i afektivnih), no hrišćanska pedagogija ide više koraka napred; ona ima garanta u Svetom Duhu (Jv. 15,26, 1 Jv. 5,6) kroz obećanog Spasitelja koji je Isus Hristos (Lk. 2,11, 2 Kor. 1,20). Na kraju, obe posmatraju ljudsko biće kao kokreatora određenog socijalnog prostora koji je u kontinuiranoj akceleraciji kulturnih identiteta, ali hrišćanska pedagogija svet tumači kao polje potencionalnosti volje Svetog Oca kroz koga stvoreno jeste "vinograd" (Jv. 15, 1), terra sacra koja se oplođuje kroz svedočanstvo i misiju. Važno je, takođe, istaći i vezu između filozofije obrazovanja i hrišćanske pedagogije koja, svaka za sebe, utvrđuju savremene kontekste i potrebe razvojnosti, pripremajući pedagoge, psihologe, nastavnike i sve one koji su involvirani u unapređenje vaspitnog obrazovanja, za izazove koje XXI vek sa sobom nosi. ${ }^{2}$

\section{Temelji hrišćanske pedagogije}

Izgonom iz Raja, ljudsko biće započinje svoju istoričku rolu koju karakteriše nemogućnost da se u potpunosti spozna odnos između Tvorca i tvari. Međutim, fundamentalni preokret nastupa dolaskom Isusa Hristosa, Iskupitelja i Obnovitelja, koji je, kroz žrtvu, ovenčao put (Mt. 11, 10) našega spasenja. Hristos jeste punktuelno određenje egzistencije i zato hrišćanska pedagogija ima zadatak "da pokaže i da neguje verovanje kao život." ${ }^{3}$ Takođe, pojedinac postoji samo kroz koegzistenciju, kooperaciju i interakciju sa svetom koji ga okružuje jer "pravilan socijalni razvoj zavisi od socijalne okoline" " a takvu okolinu obezbeđuje Crkva kojoj je glava Hristos (Ef. 1, 22). Ona poučava življenje, uzrastanje deteta do zrele ljudske jedinke koja, kroz slobodu volje, može izabrati svoj individualni model ponašanja koji će imati tu snagu da se kontinuirano preobražava ka Bogočoveku kao svemodelu.

\section{Hrišćanska pedagogija i sociologija obrazovanja}

Ako pod vaspitanjem, prvenstveno, podrazumevamo, "sveukupnost uticaja na izgrađivanje i formiranje ličnosti u skladu sa postavljenim ciljevima" ${ }^{5}$, a ta-

2 Vidi: Anthony, M. and Benson, W, 2003.

3 Lehotsky, R, 1997:11.

4 Smiljanić, V. i Toličič, I, 1990:84.

5 Milovanović, R. i Damnjanović, P, 1996:3. 
kve uticaje vrše porodica, društvene grupe, organizacije i institucije postavlja se pitanje koji je prvi korak hrišćanske pedagogije u smeru razvoja ličnosti deteta? Mnogi autori, čije mišljenje delim, smatraju socijalizaciju kao prvo, početno slovo u razvoju i razumevanju abecede života kojim dete počinje da se samotumači. Socijalizacija "jeste formiranje ličnosti kao nosioca dispozicionih svojstava značajnih za određenu društvenu zajednicu i jedinke koje žive u toj zajednici ali i formiranje ličnosti kao univerzalnog i najobuhvatnijeg sistema psihičkih pojava." ${ }^{6}$ Crkva mora, kroz naučno ustrojen sistem, da pedagogiju i didaktiku prilagodi i involvira u osnovne faze procesa socijalizacije ako želi trajan uticaj na dete. Tu svakako ne mislimo na versku indoktrinaciju ili infiltriranje bigotnih stavova, već na plansko, sistemsko i metodsko definisanje postupaka i ciljeva kroz nastavu i van nje: ' To je proces koji vodi do intelektualne konherencije i okvir je čitavog školskog kurikuluma." 7

\section{Etape socijalnog razvoja}

Osnovne etape u procesu socijalizacije su: (1)Primarna socijalizacija, koja se odvija u porodičnom krugu, a ogleda se kroz razgovor, igru i zajedničke dužnosti ukućana, može biti istkana od porodične molitve pred obed ili spavanje, do prepričavanja biblijskih motiva, igre asocijacija itd. Identifikacija kao socijalno psihološki mehanizam kod deteta je izuzetno izražena, tako da uvek treba imati na umu da otac i majka predstavljaju nukleus na kome se temelji hrišćansko vaspitanje. (2)Sekundarna socijalizacija odnosi se, prvenstveno, na školu kao instituciju u kojoj nastava, ali i učenički kolektiv, uvode dete ka sve kompleksnijim oblicima socijabilnosti. Hrišćanska Crkva, kroz osnovnoškolsku pedagogiju, morala bi da istrajava na profilaksiji spiritualnih vrednosti i ciljeva, pedagogizaciji atmosfere neophodne za školsko postignuće, individualizaciji nastave kroz koju ' '.. pojedinac realno sagledava koliko je postigao i kakav je njegov rezultat u odnosu na postignuća drugih učenika" 8 i kontrolno - savetodavni vaspitni rad. Školski savetnik - pedagog jeste osoba uvek spremna da na najbolji mogući način pruži podršku detetu koje postavlja pitanja iz najširih životnih oblasti. Savet i molitva, čime se ostvaruje blizak odnos pedagoga i učenika, mogu biti uspešni među - stadijumi dalje kultivacije i personalizacije ličnosti deteta. (3)Adolescenscijska socijalizacija je veoma turbulentan proces, koji karakteriše odbijanje

6 Ivković, M, 2003:95.

7 MacCullough, 2013:196.

8 Vilotijević, M, $2000: 199$. 
roditeljskog autoriteta i nalaženje uzora van zajednice kojoj dete pripada (glumci, pevači, sportisti ali i ljudi sa socijalnih margina). Crkva mora odlučno zauzeti komunikološko polje kroz školske i van - školske aktivnosti, pomažući detetu da samostalno pronađe Sveuzora - Hristosa. Molitva, prateći razvojne stadijume pojedinca, jeste sveobuhvatan agens socijalizacije ali i pedagoško-psihološki instrument kojim se dete identifikuje sa egzistirajućom okolinom. (4) Socijalizacija tokom odrastanja jeste kontinuirani proces u kojem pojedinac ima zadatak '...da otkrije one karakteristike i interpretacije koje su vremenski, relativno stabilne" ${ }^{9}$, prevazilazeći moguće ograničenosti sredine i utemeljujući etičke premise. Ona se, i dalje, najbolje odražava preko obrazovanja koje ide u pravcu 'permanentnog učenja, istaknutog interesovanja za profesionalnom edukacijom i treningom." ${ }^{10}$ Crkva, u životu pojedinca, može zauzeti centralno mesto, a molitva predstavlja vezivno tkivo između želja, nada i potreba.

\section{Ličnost pedagoga kao Imitatio Christi}

Hrišćanska pedagogija i didaktika nezamislive su bez pedagoga - nastavnika čiji ličnosni izraz jeste "... čvrsto integrisan, stabilan i kompleksan psihički sklop osobina, koji određuje karakteristično i dosledno ponašanje individue." 11 Sa svoje strane, sekularna pedagogija pruža naučni pristup ličnosti nastavnika savetnika kroz pedeutologiju, pedagošku disciplinu ' koja se bavi izučavanjem ličnosti nastavnika kao vaspitača" 12 i koja predstavlja emocionalno-motivacijski most između onoga što se uči i onoga ko informacije prima. Uz sve navedeno, hrišćansko vaspitanje i obrazovanje smatra krucijalnim individualnost nastavnika kao, ne samo onog koji odabira didaktička sredstva i metode, već neposredno daje primer ispravnosti cilja pedagoške delatnosti. Savetnik podučavanje započinje molitvom, tražeći blagoslov Sv. Duha, za rad koji će uslediti. On je živo svedočenje duhovne budnosti i svakodnevni primer jevanđeoske istine. Od ispravnog poimanja verskog uzdizanja i razvoja deteta zavise vrste i kvalitet pristupa hrišćanskom obrazovanju. Sa druge strane, kao i u sekularnoj pedagogiji, neophodan je aktivni komunikacijiski most ka subjektu čija je funkcija izgradnja odnosa koji se bazira na poštovanju i poverenju među svim učesnicima obrazovnog procesa, ${ }^{13}$ što vodi do (hrišćanske) vere u njenom rudimentarnom i detetu prila-

9 Oljača, M, 1996:18.

10 Jarvis, P, 1997:35.

11 Trebješanin, Ž, 2001:249.

12 Pedagoški leksikon, 1996:366.

13 Vidi: Gordon, T, 2003. 
gođenom obliku. Naravno, sve izneto podrazumeva međuzavisnost Porodične i Hrišćanske pedagogije, jer zdrav pojedinac i zreo vernik dobija početna saznanja o životu i veri još od najmlađih dana i prenosi ih kroz egzistiranje u široj socijalnoj zajednici.

\section{Metode hrišćanske pedagogije i molitva kao njen instrument}

Profesorka Rut Leohtski u svojoj knjizi "Hrišćansko obrazovanje" navodi nekoliko različitih pedagoških pristupa kojima se jevanđeoska poruka može preneti detetu. Smatramo da je integrativni deo svakog od njih upravo molitva, kao vezivno tkivo koje je u službi boljeg transponovanja svekolikog znanja u komunikacijskom lancu na relaciji učitelj - dete.

Verska instrukcija - bazični pristup u okviru verskog vaspitanja i obrazovanja jeste verska instrukcija, čiji je cilj prenošenje hrišćanskog verovanja, tradicije i prakse koja se odvija kroz grupnu i individualnu molitvu. Pedagoški pristup može biti frontalan i individualan dok obrazovni program sadrži didaktičke elemente klasičnog školskog podučavanja u kome je pedagog - učitelj i primarni organizator nastave.

Zajedništvo vere - jedan od najvažnijih aspekata duhovne arhitektonike Crkve jeste utvrđivanje zajedništva, sabornosti u veri, čija se pedagoška celovitost ostvaruje kroz naučavanje življenja u Hristosu. Instrument povezivanja deteta sa užom i širom socijalnom okolinom, koje se izražava u i kroz Crkvu, jeste molitvena praksa. Učitelj ima primaran cilj: kako da dete postane vernik.

Spiritualni razvoj - ovaj pedagoški metod priprema dete za nastupajuće doba duhovne punine. Pedagog je aktivni savetodavac, ali i medijator, dok je dete u neprekidnoj spiritualnoj tranformaciji, kako na psihičkom tako i na fizičkom planu. Tokom ovakvog načina razvoja dete urasta u zajednicu Crkve, a moljenje može biti duže, sveobuhvatnije i određenije.

Oslobođenje - Oslobođenje kao pristup usmerava dete ka ličnosti već dovoljno oformljenoj da pruža pomoć u okviru svoje zajednice onima kojima je ona potrebna. Ono postaje aktivni graditelj u istom poslu u kome se nalazi i njegov učitelj. Teži se utvrđivanju životnog stila i potvrđivanju sistema vrednosti, pa se molitva unutar verujućeg konstituiše kao svakodnevna potreba. Oslobođenje kao pristup usmerava dete ka ličnosti već dovoljno oformljenoj da pruža pomoć u okviru svoje zajednice onima kojima je ona potrebna. Ono postaje aktivni graditelj $\mathrm{u}$ istom poslu u kome se nalazi i njegov učitelj. Teži se utvrđivanju životnog 
stila i potvrđivanju sistema vrednosti, pa se molitva unutar verujućeg konstituiše kao svakodnevna potreba.

Tumačenje - Hrišćanska Crkva i škola kroz navedeni metod rade na prožimajućem povezivanju savremenog načina života i religijske stvarnosti, oblastima u kojima dete paralelno egzistira. Učitelj-pedagog je saputnik i sabesednik; onaj koji poznaje životne epizode i koji ima odgovor na novonastala pitanja. Pedagog i dete mole, zajedno i samostalno, svedočeći o povezanosti između verovanja i Božanskog prisustva u sadašnjosti.

\section{Programiranje pedagoškog rada i molitvenost}

Svaka obrazovno-vaspitna aktivnost, u školi ili van nje, mora biti planirana i programirana tako da se uspešno mogu ostvariti pedagoški ciljevi i zadaci. Programiranje rada verskih i sekularnih škola ' ...predstavlja takvu selekciju i konkretizaciju sadržaja, sredstava, oblika, metoda rada, predviđanja i utvrđivanja vremena i nosilaca pojedinih programskih zadataka, koje obezbeđuje da se u datim vremenskim okvirima kvalitetnije realizuje veći broj zadataka i da se postignu bolji vaspitno-obrazovni efekti" ${ }^{14}$ kome je svrha znanje kao "pouzdana reprezentacija ili mapa stvarnosti." ${ }^{15}$ Međutim, hrišćanska pedagogija i didaktika postoje samo kroz hristocentrično dvostruki totalitet: i znanje, ali i verovanje - i informacija, ali i moralno uzdizanje. Bez obe komponente nema pravilnog razvoja! Molitva, sa svoje strane, jeste aksijalan meta - prostor: ona je i prozor apsolutnog sada do u večnost i reverberativnost Večnog u sadašnjosti. No, šta je, zapravo molitva?

\section{Molitva je "Uvođenje uma Bogu"}

Ove reči Svetog Jovana Damaskina i danas snažno odjekuju u svesti hrišćana ma kojoj Crkvi pripadali. Ali, ako želimo da ovu misao donekle proširimo, rekli bismo da molitva neizostavno mora uključivati stvarnost dijaloga sa Bogom i permanentnost zajedničarenja Boga i ljudi. Još preciznije rečeno, ' '... upražnjavanje molitve pretpostavlja Božije prisustvo u čovekovom iskustvu i njegovo lično obraćanje pojedincu" ${ }^{16}$ kroz koju se, ne samo traži, već i ispoveda vera. Mnogi teolozi izdvajaju posebne oblike moljenja: molitve slavljenja, molitve blagodar-

14 Mandić, P. i Vilotijević M, 1976:20.

15 Ristić Ž, 1995:30.

16 Enciklopedija živih religija, 1990:472. 
nosti, molitve ispovedanja, molitve zahvalnosti, molitve prizivanja i posredničke molitve. Ovakva podela pomalo je kruta, jer ne uzima potpuno u obzir ljudsko biće kao ono koje je u stalnom emocionalno-duhovnom previranju, ali ma šta pojedinac osećao, želeo ili očekivao, molitva je uvek prisutna kao vodič do spoznaje Božanske milosti.

Isus Hristos kroz svoju iskupiteljsku misiju podučava svoje učenike molitvi. Ona se u Svetom pismu Novog zaveta, kao termin koji označava zajedništvo sa Gospodom, pojavljuje 71 put, a sam Spasitelj kroz molitvu ' Oče naš” (Mt. 6, 9, Lk. 11, 2) daje nam tačne instrukcije koje pružaju temelj lične bogoslužbenosti. Postavljajući osnovu živuće povezanosti između verujuće individue i Boga, Isus Hristos, ovaplođujući princip učeništva, kao način prenošenja znanja, ukorenjuje molitvu u kojoj je njegovo ime za pojedinca i grupu štit vere i simbol kojim se pobeđuje. Realnost Hristovog naukovanja molitve ogleda se kroz ' traženje i primanje; traženje sve dok se ne primi blagoslov, dok se ne dobiju uverenja da Bog čuje i dok se ne doživi da je Njegova sveta prisutnost tu." ${ }^{17}$ Crkva, uvodeći mlade u veru, ostvaruje plan Svetog Sina koji je došao zbog svakog, pojedinog ljudskog bića dok detinjstvo predstavlja koren na kome raste rajsko drvo puno plodova iskupljenja.

\section{Molitvenost kroz razvojni identitet deteta}

Preobraženje vaspitanjem svakog ljudskog bića počinje prvim danom, prvim dahom njegovog života na Zemlji. Vaspitavanje verom i kroz veru jeste poseban, celoživotni proces u kome znanje mora ustupiti mesto empiriji, a ljubav prema svemu stvorenom katehetičkom promišljanju. Dete se može razviti u zrelu, Isusom inspirisanu jedinku, samo ako se ispunjava sledeći uslov: roditeljski par mora biti okrenut Bogu rečju i delom, sa molitvom kao oruđem vere. Tako opremljeni, odrasli smeju računati na izvesnost milosti i spokoja za sebe i dete koje pravi svoje prve korake ka ustalasaloj pučini života.

\section{Dete u dobi od rođenja do 3. godine}

Nakon prvog plača, prvog znaka kojim dete sebe oglašava, postepeno se uspostavlja biološko - psihološki ekvilibrijum koji je rađanjem bio narušen, dok svaki novi mesec života otvara mališana ka utiscima iz spoljne sredine. Pred kraj prve godine pa sve do treće dete istražuje oblike iz svoje okoline i prepoznaje

17 Simov, D, 1996:144. 
najbliže članove porodice. 'Objektivna usmerenost ovog razdoblja očituje se radosnim i ekspanzivnim mirom." ${ }^{18}$ Opisanu fazu zamenjuje oko treće godine uzburkanost otkrića jastva; kinestetički napredak je u ekspanziji, a dodir sa poznatim i zabavnim objektima, kojima dete svakodnevno manipuliše, izaziva pozitivnu emocionalnu napetost. Reč, odnosno govor, prouzrokuje novu vrstu interesovanja za živi svet kome se dete sve češće obraća, a inteligencija i ljubav se sve više prepoznaju kao elementarijum kojim se fundira ličnost.

\section{Pozicioniranje majke}

U najranijoj fazi detinjstva porodični dom mora biti 'najvažnija vaspitna sredina" dok roditelji počinju da ostvaruju saradnju 'sa brojnim društvenim institucijama koje se brinu o zdravlju, vaspitanju i obrazovanju" ${ }^{19}$ pri čemu je majka najvažnija figura u procesu vaspitanja. Ona zadovoljava primarne životne potrebe ali i pruža sigurnost, toplinu i razumevanje. Majka u tom dobu predstavlja osovinu formiranja budućeg moralnog bića deteta.

\section{Molitva najmlađih}

U pogledu verskog usmeravanja deteta majka je takođe centralna ličnost, od koje prvi put čuje reči kao što su Bog, dobrota, ljubav... Iako detetu u prvoj ili drugoj godini takvi pojmovi malo znače, ono počinje da se navikava na specijalan odnos koji roditelji imaju prema pomenutim pojmovima; majka i otac mole za dete i ono, vrlo rano, shvata da je Bog nešto važno, nešto neizostavno. Međutim, kako se Bogu obratiti, šta Mu reći? Molitva deteta između druge i treće godine prvenstveno mora biti kratka i sažeta, uz naglašenu važnost poruke koja mora biti odraz dečije svakodnevnice. Roditelji i dete mogu moliti na sledeći način: "Veliki Bože, tvoja te Vesna voli." ${ }^{20}$ Dete mora stići do poverenja sa Bogom, kome sme poveriti svoje male tajne. Gospod postaje prijatelj; On bdi, voli i razume dete koje uzvraća najbolje što ume. Spoljna forma molitve ne sme biti rigidna, bez specijalnih gestova ili prevelikih fizičkih zahteva. Dete ovoga doba je spontano i živo, uvek spremno za igru i istraživanje, tako da molitva mora biti ugodna, da bi dete, kroz prirodnost ponašanja, moglo da uživa. Podržimo mališana ako, dok moli, tapše, smeje se ili skače, jer smisao molitve nije u pokornosti već u ljubavi. Kada govorimo o vremenu

18 Colomb, J, 1981:25.

19 Kamenov, E, 1987:78.

20 Leist, M, 1986:20. 
kada dete moli, smatram da je veče, odnosno odlazak na spavanje, najbolji trenutak za molitvu i razmišljanje. Povremene molitve uz porodični ručak jesu snažan kohezioni faktor, jer članovi dele istu tajnu, isti cilj, a to je milost Božja. Život molitve jednog zdravog deteta ogleda se u nenametnutom načinu ispoljavanja vere od strane roditelja, ali uz svakodnevnu svest istih da razvoj svih ljudskih vrednosti zavisi od kvaliteta verskog života odraslih koji se manifestuje kroz jasnu moralnu čistotu i delovanje. Molitva prijanja uz dete; ona je adaptibilna u načinu, ali čvrsta u poruci.

\section{Dete u dobi od 3. do 6. godine}

Ovaj životni ciklus označen je prvom krizom identiteta koja se ogleda kroz protivljenje okolini i ekspanziji "ja" nametanjem volje i menjanjem oblika ponašanja. Psihološka potreba da se biva u centru sveta već je evidentna, a težnja za potpunim ovladavanjem telom govori o neminovnom osamostaljenju koja će, u jednom trenutku, dovesti do puberteta. Kroz ovu fazu izgrađuje se svesnost, govor je već jasan i razgovetan, duševne snage se uobličuju. Misao je, još uvek, veoma subjektivna, a savest zavisi isključivo od savesti roditelja i vaspitača.

\section{Uloga roditelja}

Pored predškolskih vaspitnih ustanova, roditelji su, i dalje, glavni pedagozi i savetnici koji poznaju i tumače sve jasniju stvarnost kojoj se dete divi. Otac postaje sve važniji - samostalnost, borbenost, autonomnost imanentne su očevoj figuri, dok na moralno vaspitanje utiču oba roditelja. Oni podučavaju dete saradnji i kooperaciji s drugima razvijajući altruizam i humani odnos naspram živuće okoline. Za roditeljski par, u savremenom post-industrijskom društvu, veoma je važno povezivanje sa mnogobrojnim institucijama koja vode brigu o zdravlju i razvoju dece, a Crkva, sa svoje strane, kroz ustanove predškolskog tipa, jeste spona između unutrašnjih dispozicija deteta i prevazilaženja diskontinuiteta koji je prisutan između mališana i sveta odraslih.

\section{Moć molitve}

Stadijum na kojem je dete sa četiri i pet godina predstavlja vreme zrelosti za osnovna saznanja o Bogu. Dete može shvatiti da je Bog snažniji i moćniji od roditelja, dok sa druge strane Bog sve više uzima udela u svakodnevnim radnjama deteta; ono, kroz molitvu, prepričava sve što mu se događa - igru sa drugovima, raz- 
govor sa najbližima, želje za novim igračkama. Bog je povezan sa jelom i pićem, suncem i radošću, ali postoje i bolest, i smrt. Dete moli uz roditelje za zdravlje sestre ili bake, a posmatrajući molitvu roditelja u teškim trenucima gubitka voljene osobe, mališan, kroz njihovo uverenje o Božijoj dobroti uprkos smrti, počinje da uviđa da je Bog uključen u svaki aspekt stvarnosti, ma kako on neshvatljiv bio. Posredstvom molitve u tom dobu dete se uči otvorenosti, iskrenosti i neophodnoj emotivnoj samorealizaciji. Moć molitve ogleda se u približavanju Božije sveprisutnosti dečijem umu. Takođe, molitva može imati i posredničku moć među članovima porodice, odnosno braće i sestara. Ukućani mole za promenu odnosa među decom ukoliko se jave zavist, ljubomora ili jarost. Treba naglasiti: dete želi dokazati samostalnost, a molitva je način očovečenja. Ona služi da već stasali mališan svojim rečima, na svoj način izmoli od Boga milost pažnje, jer svaki hrišćanin, pa i onaj najmanji, ' '.. je mali Hrist. Ali svaki hrišćanin je mali Hrist na svoj vlastiti način." ${ }^{21}$ Istinska moć molitve je ona koja proizilazi iz neutažive čežnje duše da se neponovljivost ličnosti približi svom božanskom idealu - hristolikosti u sebi.

\section{Dete u dobi od 6. do 9. godine}

Navedeno razdoblje može se okarakterisati kao doba razuma čije su karakteristike naglašena objektivizacija i buđenje savesti koje pozitivno utiču na preuzimanje socijalne inicijative podstaknute kretanjem u školu kao novog misaonog izazova. U sedmoj i osmoj godini dolazi do nagle interiorizacije sveta odraslih kroz hijerarhizaciju odnosa u njihovim zadatim relacijama. Konativni aspekti ličnosti naglo se učvršćuju kroz autonomiju ukusa, zaključaka ili dužnosti u odnosu na roditelje, dok greška i krivica postaju elementi etičkog prosuđivanja. Iako savest još uvek nije oblikovana zakonima koje propisuje društvo, dete želi da bude dobro i produktivno, pohvaljeno i podržano. Život škole određuje uzajamnost i nesebičnost kao i težnju za druženjem i udruživanjem u okvirima razredne zajednice. Dete prihvata ili odbija, poslušno je ili prkosi, ali svaka akcija poprima autonomnu fizionomiju bihejvioralno - afektivne prirode; ono ume da praktikuje život i u njegovim okvirima veru.

\section{Molitva zrelog detinjstva}

Molitva koju dete praktikuje uvek mora biti odraz i srca i razuma, bez moralizatorskog prizvuka ili naglašene katihetske poruke. Ona podstiče na delovanje,

21 Hendricks, W, 1996:163. 
na stvaranje najpogodnijeg načina za dijalog kroz koji i divljenje i zahvalnost, ali i briga i tuga stižu do pravog značenja. U tom razdoblju dete sve više želi da se osamostali u moljenju, ali ne nalazi uvek adekvatne reči ili izraze, tako da i šablonizovana molitva ima svoju odgovarajuću formulacijsku vrednost. Pesma, igra, crtanje i slikanje, umesto krutosti, dobar su recept za razvoj molitvenog raspoloženja našeg deteta. Roditelji, nastavnici i savetnici moraju zajedničkim snagama da detetu predstave molitvu kao stvaralačku radionicu duha. Ona se ogleda kroz pokret, osmeh, boju koje dete bira po svom unutrašnjem ličnosno-estetskom senzibilitetu, kroz uvek prisutnu razvojnu napetost koju molitva može nanovo valoralizovati i kanalisati svojim snažnim komunikacijskim fokusom.

\section{Isus Hristos kao lični Spasitelj}

Dete ovih godišta još uvek je deo svog samokreirajućeg fantastičnog sveta u kome su čuda moguća. Isus je detetu pojmljiv kroz zanimljive priče i čuda koje prenose njegovi bližnji. On je velik i moćan, no vremenom postaje stvaran, zaogrnuvši se ljudskom prirodom. Kao i porodica, i Crkva može biti iznad svakodnevnog poznatog sveta, u kome dete, kroz rast i razumevanje biblijskih poruka, prihvata Isusa kroz njegovu božanstvenost, koja će u budućnosti predstavljati stepenice ka otkupljujućoj, bogočovečanskoj misiji Hristosa. Dete i Isus imaju zajedničku tajnu - prijateljstvo.

\section{Dete u dobi od 9. do 12. godine}

Objektivizacijom svesti kroz intenzivnost socijalnih odnosa prvi put se javlja apstraktna ideja uz vremensku povezanost događaja. Dete između jedanaeste i dvanaeste godine života sposobno je odrediti prilike i odnose koji mu sve više znače i u kojima sve više želi učestvovati. Misao je analitična uz sposobnost spoznaje objekata kao takvih. Logičnost i analitičnost, kroz moć klasifikacije, zauzimaju mesto egocentrizma; okrenutost prirodi je velika škola, a učenje postaje konkretna potreba koju dete sve lakše ispunjava. Dete širi svoje vidike koje karakteriše dijalog, suočavanje i tumačenje; osoba kojoj se obraća postaje saradnik, ali i oponent kroz takmičarske igre i sport, kroz koje uspeva da transponuje sve kompleksniji unutrašnji svet. Dete počinje da gradi autoritet među vršnjacima a pojedinci osvajaju i lidersku poziciju, sa izraženom konformističkom crtom. Moral se shvata kao dužnost, pa se samim tim i racionalizuje i vezuje se za opštost pravila koja važe u kolektivu. Katihetsko obrazovanje može biti daleko konkret- 
Sergej Beuk: Prilozi teoriji hrišćanske pedagogije: molitva kao agens socijalno...

nije, moguće je predočavanje kompleksnijih biblijskih istina ali i smisla crkvenog života i svrhe Božje objave u vremenu.

\section{Molitva rađajućeg zajedništva}

Molitveni život deteta ovog stadijuma mora posedovati onaj neponovljivi pečat, koji svako dete razlikuje od zajednice odraslih kojoj pripada. Kako Crkva vremenom postaje posrednik između lične molitve i socijalizacije, vaspitači i medijatori dečijih grupa svoj rad moraju sve više usmeravati ka kontekstualizaciji i konkretizaciji molitvenog tematizma, jer deca ovoga doba intenzivno žele da participiraju u grupi, timu sa zajedničkim ciljem koji se ostvaruje kroz utvrđena, ali ne i shematizovana pravila. Dete već dugo moli samo, no bura duha je jaka: zapitanost, osećaj nepravde, sloboda ispoljavanja identiteta u i kroz kolektiv - svi ti i mnogi drugi elementi, psihološki, pedagoški i sociološki, utiču da dete oseti potrebu za zaštitom i odgovorom kroz molitvenu omladinsku grupu u kojoj voditelj ima posebno istaknutu ulogu. Medijator grupe prilagođava atmosferu pogodnu za zajedništvo molitve, prepuštajući sadržaje molitvi članovima grupe, kroz određene njene vidove. Profesorka Rut Lehotski, u knjizi "'Versko vaspitanje" navodi neke od njih: lančana molitva, molitvena straža, "vođena molitva" ali i njihova kombinacija ostavljaju pojedincu i grupi dovoljno prostora da se adekvatno i iskreno pokaže i neguje prisan odnos sa Gospodom. ${ }^{22}$

\section{Značaj savetodavnog pedagoškog rada}

Svako pedagoško savetovanje, samostalno ili u grupi, ima smer ka pojedincu. Molitvena zajednica mladih, uz voditelja - pedagoga, neprekidno teži ka proširivanju dinamizma molitvenog aktiviteta i njegovih struktuiranih sadržaja. Pedagog, u navedenim uslovima ima jasnu ulogu: ' (1)Podstiče ostvarivanje ciljeva grupe, (2) Pomaže grupi da identifikuje zajedničke probleme, (3)Nastoji da razvija zajednička osećanja članova grupe, (4)Podstiče članove grupe da dele zajednička iskustva, (5)Podstiče konstruktivna pitanja, (6)Prihvata sa respektom svačiji doprinos u radu grupe, (7)Podstiče devizu 'uloži i dobij" među članovima grupe, (8)Podstiče ispoljavanje emocija, (9)Stimuliše samostalno mišljenje i (10)Pomaže grupi da identifikuje i izabere vođu." ${ }^{23}$ Pedagog se mora stalno prilagođavati grupi rešavajući moguće interakcijske probleme ' 'kroz dijagnostiku i korekciju pedagoške komunika-

22 Vidi: Lehotsky, 1980.

23 Trnavac, N, 1993:167. 
cije, stila rukovođenja, vežbanje komunikacije" ${ }^{24}$, vodeći računa da svaki član dobije dovoljno mesta za iskazivanje sopstvene ličnosti kroz molitvu.

\section{Dete u dobi od 12. do 15 . godine}

Naznačeno doba psiholozi često nazivaju predpubertetom ili predadolescencijom i karakteriše ga realniji odnos prema svetu uz neumitno gubljenje detinjih i građenja novih ideala, veća okrenutost projekciji budućih događaja naspram sadašnjosti kao i duh pobune i neprilagođenog ponašanja naspram pravila koje diktiraju odrasli. Egocentrička disperzivnost uz snažnu afektivnu akceleraciju jesu osovinske tačke koje karakterišu ovu fazu razvojnosti. Dete teži ka ravnoteži smisla i slobode, ka ratio iznad nagona; kroz impulsivnost i negativitet dete se bori za nezavisnost ali i za sve kompleksnijim primerima identifikacije. Predadolescent teži da u okvirima učeničkog kolektiva izdvoji podgrupu istomišljenika tako da školski razred, kao celina, gubi na značaju. Unutrašnji, misaoni svet pobuđuje sve snažnije interesovanje, iz čega sledi jasnije razumevanje odraslih kroz njihove probleme i odluke. Ambicioznost i studioznost u ovom dobu nalaze svoje zdrave korene, uz napomenu da verski život, po prvi put, počinje da biva preispitivan i analiziran. Crkva i njeni radnici - pastiri i katihete - pedagozi, morali bi aktivno i čvrsto uticati na novonastalu psihološku stvarnost kroz pružanje oslonca - Hristosa kao junaka i pobednika; Onoga koji ostaje prisutan nakon svih kriza i kolebanja.

\section{Molitva poverenja}

Predadolescent, težeći činjenicama religioznog realizma, kroz molitvu pokazuje emocijska previranja, ali u isto vreme i žeđ za sigurnošću i nepromenljivošću. Sadržaj lične molitve razgovetan je i jasan; dete zna šta ne želi i neće i od Boga očekuje razumevanje, no Bog je onaj koji razreševa krize tako da poverenje u božansku svemoć jeste ključ i most između deteta koje postaje odraslo ljudsko biće i Gospoda koji je uvek prisutni Duh Utešitelj. Voditelj molitvenih grupa mladih mora biti specijalno pripremljen za rad sa decom predadolescencijskog i adolescencijskog doba zbog specifičnosti navedenog razvojnog stadijuma: vedrina, istrajnost i jasnoća moraju preduprediti moguće antagonizme u okvirima grupne molitvene dinamike. Medijator zadobija poverenje deteta time što svedoči i moli zajedno sa grupom, prepuštajući, postepeno, inicijativu članovima koji žele da iskustva i dileme podele sa drugima. Molitva postaje način potencijalnog razrešenja. Za-

24 Ovčareva, R, 1996:82. 
jednica pruža ohrabrenje da se kroz molitvu duša okrene Bogu i nađe preko potreban odgovor na sva pitanja koja mogu biti od značaja za trenutni ali i budući život.

\section{Savršenstvo}

Kako je u navedenom periodu dete u značajnim intimnim previranjima, izmenjeni pojmovni aparat podrazumeva i kvalitativno obogaćenu transcedentnu odrednicu Boga koja ide u pravcu sve ličnijeg i određenijeg poziva detetu za savršenstvom i oslobađanjem. Gospod je savršen i upućuje na savršenstvo! Dete je već upoznalo Hristosa kao prijatelja i saradnika, ali Isus je tajna, a pojedinac želi sve snažnije da tu skrivenost odgonetne. U Crkvi, ali i u svakodnevnom životu dete nalazi Boga sledeći Njegov sveti primer, koji je u svemu. Ali tu nije kraj, jer kroz Njega dolazimo do Svetog Oca, posredstvom Svetog Duha koji donosi darove razumevanja i istinske ljubavi.

\section{Dete u dobi od 15. do 18. godine}

Period adolescencije karakteriše vanredno interesovanje deteta za izgrađivanjem sopstvene ličnosti. Priroda ovog razvojnog stadijuma leži u naglašenoj subjektivnosti: promišljanje svetskih događaja prilagođava se intrinzičkim kognitivnim shemama uz prisutnost idealističkih stavova i stremljenja. Adolescent, zaokupljen vlastitošću, kuca na vrata postojeće kulturne okoline, sve više postavljajući fundamentalna pitanja kroz predmetno - naučnu, ali i kroz umetničku akciju u kojoj ceni iskrenost osećanja i posvećenost. Prisutno je sanjarenje i sklonost ka apstrakciji, strastvenom divljenju i apsolutiziranju sopstvenih procena. $U$ isto vreme, adolescent ume lako skliznuti ka nagloj promeni estetskog ukusa, ka preziru i zaboravu. Kroz navedeni dijalektični odnos, u kome se pojedinac svakodnevno nalazi, psiholozi, ali i Crkva imaju zadatak da ispune novonastali vakuum jezgrovitim socijalno - pedagoškim sadržajima koji će podstaći dete na samostalno traganje za istinom. Hrišćanski savetnik, probijajući se kroz buru adolescenske promenljivosti duha, omeđuje svet deteta kroz sigurnost i stalnost sveobuhvatne snage vere.

\section{Molitva intersubjektivnog delovanja}

Spoznajna bipolarnost i česta emotivna prenaglašenost odražavaju se i na molitvu. Adolescent od Boga traži konkretne, bezuslovne odgovore nudeći sebe kao instrument božanske sile odgovora. Individualna molitva, takođe, predstavlja i vre- 
me mira i sabranosti od svakodnevne vreve. No, treba istaći, dete toga doba, često od molitve očekuje nemoguće, dovodeći autoritet Božjeg vođstva u sumnju. Postavlja se pitanje: šta u tom slučaju čini Crkva i njeni pedagoški delatnici? Odgovor leži u aktuelnosti sadržaja koji zaokupljaju mlade i koji se, uspešno, mogu osvetljavati i razrešavati kroz individualnu i grupnu molitvu. Voditelji molitvenih grupa pozvani su na temeljnu i unapred osmišljenu programsku akciju u kojoj će susret sa Bogom biti primeren mladima i njihovim individualnim problemima. Nakon uvodne molitve medijatora grupe, mladi mole kroz razgovor, iznoseći svoje dileme pred vršnjake sa kojima se najbolje razumeju, čineći tako molitveni krug u kome se razmenjuju i naglašavaju zajedničke praktične i spiritualne potrebe. Adolescenti često žele da mole zajedno sa pedagogom - voditeljem i njegova je uloga da u svakom trenutku bude u stanju da savetodavno uskladi molitvu pojedinaca sa potrebama grupe čiji su članovi. Molitveni život mladih je, u grupnom smislu, snažno interakcijski a u individualnom intersubjektivan jer pojedinac traži i teži Božijem odgovoru koji razume kao samo njemu znan i važan. Pitanja, dileme, osujećenosti i krize još neformirano ljudsko biće oseća i kroz molitvu predstavlja kao totalitet subjektivizirane realnosti u kojoj jedino Bog ima svoj jedinstveni odgovor. Crkva kao riznica, kao repozitorijum tajne iskupljenja, putem Hristosa, obezbeđuje pravilne uslove za svaku mladu jedinku koja tim putem želi stremiti.

\section{Moralnost i vera}

Socijalni svet otvoren je mladom čoveku za ostvarivanje vrednosti kojima prirodno teži: studije, profesionalno usmerenje, brak... sve to stoji pred adolescentom očekujući njegov hrabar korak ka samostalnom životu. U ovom periodu, najznačajniji moralni osećaj je samopoštovanje koje se realizuje kroz autonomne izbore važne za budućnost. Prisutni su i osećaji obaveze, vernosti i poštenja - neobično važne komponente budućeg religioznih stremljenja. Iako intimna, vera adolescenta postepeno postaje vera Crkve, ostvarujući eklesijalni dinamizam zajednice kroz lični doprinos poslanja od strane Boga. Etičke i verske smernice slivaju se u jednu reku, dajući zamajac egzistenciji koja hrli nezaustavljivo napred.

\section{Hrišćanska andragogija, katiheza i molitva}

Hrišćanska pedagogija i didaktika, kroz ' ... savetovanje, profesionalno usmeravanje i edukološku objektivizaciju" ${ }^{25}$ a na osnovama biblijskih vredno- 
sti, želi da adolescenta uvede u svet bio-psihičke, intelektualne i radne zrelosti. Međutim, obrazovno-duhovne potrebe ne gase se sa punoletstvom, već još jasnije izviru na površinu kroz slobodnu socijalnu delatnost $\mathrm{u}$ kojoj pojedinac participira. Hrišćanska andragogija ima za cilj organizovanje i sprovođenje obrazovnih teorija i modela koje subjekt usvaja kroz i uz rad, slobodno vreme, mas-medije i savremene obrazovne tehnologije, a čiji je smisao u sprovođenju hrišćanskih doktrina u okvirima modernog načina življenja. Katihetika odraslih, sa svoje strane, produbljuje znanje i veru baveći se sledećim temema: Isus Hristos i duhovna akcija, greh i njegove implikacije, Carstvo Božje i Crkva, darovi Svetog Duha, hrišćanska porodica i uloga žene, itd. Molitva jeste alfa i omega svake aktivnosti; bilo da se profesionalno usavršavamo, vaspitavamo najmlađe ili pomažemo siromašne, molićemo usrdno za Božiju svetu prisutnost, jer bez Njega ništa nije moguće. Kao početak, sredina i kraj Gospod je sve u svemu...

\section{Zaključak}

Čežnju za preoblikovanjem i rekreacijom ljudsko biće je, kroz istoriju, iskazivalo na mnogo načina i u mnogo paralelnih dimenzija. Jedna i najstarija od tih dimenzija je vaspitanje mladih naraštaja koje je, u svojoj permanentnosti, uvek ukazivalo da tok ljudske civilizacije može ići samo u jednom pravcu - usavršavanju učenjem.

Isus Hristos, ovaploćeni Bog, pružio je primerom rešenje: kroz uravnoteženje ka svetlu spasenja, kroz šumu izazova do mirne plaveti pučine ljubavi. Kroz Njega, posredstvom Svetom Duha, Crkva obezbeđuje da karakterologija pojedinca bude izražena, ali i prevaziđena Jednim i Jedinim izvorom svekolikog postojanja.

Hrišćanska pedagogija jeste priprema ostvarenja Carstva Nebeskog i pruža se u svim pravcima - od porodice, preko osnovne i srednje škole, univerziteta do čitavog društva pravila i institucija. Ona je i način obezbeđivanja jasnije vizije, do u večnost izvesnosti spasenja. Ljudsko biće, u njenim rukama, postaje oblikovana glina, formirano delo na slavu Tvorca i Njegovog promisla. A molitva je uvek tu: ona je instrument i thovanje, odjek i vojevanje - hleb vere i način bivstva. Dete molitvom voli i u ljubavi moli.

Evangelizacija dece i mladih oglašava pedocentričku usmerenost Crkve koja kroz pedagoško - didaktičku realizaciju raste zajedno sa najmlađima i obezbeđuje sigurnost života misije u sadašnjem i budućem vremenu. 


\section{Literatura}

Anthony, Michael and Benson, Warren, Exploring the History and Philosophy of Christian Education: Principles for the 21st Century, Kregel Publications, Grand Rapids, 2003.

Colomb, Joseph, Kateheza životnih dobi, Salezijanski provincijalat, Zagreb, 1981.

Enciklopedija živih religija, Nolit, Beograd, 1990.

Gordon, Tomas, Kako biti uspešan nastavnik, Kreativni centar, Beograd, 2003.

Hendricks, William L., Teologija za decu, LDI, Veternik, 1996.

Ivković, Miomir, Sociologija obrazovanja 1, Filozofski fakultet u Nišu, Niš, 2003.

Jarvis, Peter, The Effects of Globalisation on Adult Education in the United Kingdom, Institut za pedagogiju i andragogiju filozofskog fakulteta u Beogradu, Beograd, 1997.

Jones, Anna, Counselling adolescents in School, Kogan Page Limited, London, 1977.

Kamenov, Emil, Predškolska pedagogija, Zavod za udžbenike i nastavna sredstva, Beograd, 1987.

Kembel, Ros, Kako stvarno voleti svoje dete, Alfa i Omega, Beograd, 2003.

Lehotsky, Rut, Hrišćansko obrazovanje, BBC “'Logos”, Novi Sad, 1997.

Lehotsky, Rut, Versko vaspitanje, Baptistička teološka škola, Novi Sad, 1980.

Leist, Merielene, Prva iskustva o Bogu, HKD Sv. Ćirila i Metoda, Zagreb, 1986.

MacCullough, Martha, By Design: Developing a Philosophy of Education Informed by a Christian Worldview, Cairn University, Langhorne, 2013.

Mandić, Petar i Vilotijević, Mladen, Programiranje rada škole, IP "Svjetlost" - Zavod za udžbenike, Sarajevo, 1976.

Miletić, Dragiša, Biblijsko - bogoslovski rečnik, Fototipsko izdanje pravoslavne eparhije dalmatinske, Šibenik, 1934.

Milovanović, Radojko i Damnjanović, Predrag, Osnovi andragogije, Policijska akademija, Beograd, 1996.

Oljača, Milka, Self koncept i razvoj, Filozofski fakultet Novi Sad, Novi Sad, 1996.

Ovčareva, Raisa, Psiholog $i$ pedagog $u$ školi, Učiteljski fakultet - Centar za stručno usavršavanje, Beograd, 1996.

Pedagoški leksikon, Zavod za udžbenike i nastavna sredstva, Beograd, 1996.

Potkonjak, Nikola, Opšta pedagogija,Učiteljski fakultet, Beograd, 1996.

Ristić, Živan, O istraživanju metodu $i$ znanju, Institut za pedagoška istraživanja, Beograd, 1995.

Simov, Dragan, Šta kaže Sveto pismo, Alfa i Omega, Beograd, 1996.

Smiljanić, Vera i Toličič, Ivan, Dečja psihologija, Zavod za udžbenike i nastavna sredstva, Beograd, 1990.

Trebješanin, Žarko, Rečnik psihologije, Stubovi kulture, Beograd, 2001.

Trnavac, Nedeljko, Pedagog u školi - Prilog metodici rada školskog pedagoga, Učiteljski fakultet, Beograd, 1993.

Vilotijević, Mladen, Didaktika 3, Učiteljski fakultet, Beograd, 2000. 
84 Sergej Beuk: Prilozi teoriji hrišćanske pedagogije: molitva kao agens socijalno...

\title{
Sergej Beuk
}

Dom omladine Beograda

\section{CONTRIBUTION TO THE THEORY OF CHRISTIAN PEDAGOGY: PRAYER AS AN AGENT OF SOCIAL - PSYCHOLOGICAL DEVELOPMENT OF CHILDREN AND YOUTH}

\begin{abstract}
Summary
In this study, author wishes to emphasize theoretical relations between secular and Christian pedagogy, field which is not enough researched in our society. Academic roots of contemporary Christian pedagogy can be found in Holly Scriptures teaching. This discipline than continues its growth following other scientific disciplines such as personal psychology, development psychology, psychology of pedagogy, general psychology, didactics and others. For Christian educators, Christ is an anthropological aim, but neglecting of scientific research results leads undoubtedly into dogmatization and doctrinaire digression of both Christian educators and Christian pedagogy in totality. Author underlines that the prayer is that discipline of the mind that has double educational effect: free research of ones needs through specific form of communication and ones direction through prayer, both by the parent and educator, aiming to develop new capabilities and habits of a child. The Church today has a task to educate the Young in present times, understanding their needs and aspires, which is not at all an easy job.
\end{abstract}

Key words: child, prayer, Christ, Church, development, Christian Pedagogy 